Jurnal MAKSIPRENEUR, Vol. III, No. 2, Hal 58 - 84

\title{
ANALISIS TINGKAT KEPUASAN NASABAH TERHADAP DIMENSI KUALITAS LAYANAN PADA BPR BDE PAKEM SLEMAN DENGAN PENDEKATAN IMPORTANCE- PERFORMANCE ANALYSIS
}

\section{Andriya Risdwiyanto (andriyarisdwiyanto@gmail.com)}

Fakultas Ekonomi Universitas Proklamasi 45

\begin{abstract}
The survey was conducted in the research process to determine the level of customer satisfaction on service quality dimensions of Rural Bank Bakti Daya Ekonomi (BPR BDE) Pakem Sleman, Yogyakarta and to determine the dimensional attributes of services which one is considered the most important by the customer in the decision-making of services using in BPR BDE Pakem Sleman, Yogyakarta. This research is based on five variables, namely SERVQUAL i.e. Reliability (ability of the company to provide prompt service and reliable), Responsiveness (response-ability or alertness companies to help customers and provide fast service), Assurance (ability, courtesy, and trustworthiness which is owned by the staff, danger free, risk, and doubt), Empathy (the ease of having good communications and able to understand customer needs), and Tangible (physical facilities, equipments, employee performance, and means of communications). The analysis is performed based on an approach of importance-performance analysis that show the dimensions of empathy and assurance are considered the most influence on the customers decision to use the services of BPR BDE Pakem Sleman, Yogyakarta.
\end{abstract}

Keywords: marketing, service quality, customer satisfaction, survey.

\section{A. LATAR BELAKANG MASALAH}

Dalam setiap kegiatan bisnis sehari-hari, kualitas dipandang sebagai salah satu alat untuk mencapai keunggulan kompetitif, karena kualitas merupakan salah satu faktor utama yang menentukan pemilihan produk barang dan jasa bagi konsumen. Kepuasan akan tercapai apabila kualitas produk dan jasa yang diberikan sesuai dengan kebutuhan, dan sesuai dengan apa yang diharapkan. Kualitas merupakan salah satu nilai 
penting yang sangat berpengaruh pada kepuasan konsumen. Memahami bagaimana mengevaluasi kualitas yang diterima oleh konsumen tidaklah mudah, utamanya untuk produk berupa jasa. Kualitas jasa diberikan selama penyerahan jasa terjadi dalam proses interaksi di antara konsumen dan terdapat kontak personal dengan jasa tersebut.

Menurut Schnaars (dalam Tjiptono, 2005, hal. 199), pada dasarnya tujuan suatu bisnis adalah untuk menciptakan para pelanggan yang merasa puas. Terciptanya kepuasan pelanggan dapat memberikan beberapa manfaat, di antaranya hubungan antara perusahaan dan pelanggannya menjadi harmonis, memberikan dasar yang baik bagi pembelian ulang dan terciptanya loyalitas pelanggan, dan membentuk suatu rekomendasi informasi dari mulut ke mulut (word of mouths) yang menguntungkan bagi perusahaan. Ada beberapa pakar yang memberikan definisi mengenai kepuasan/ketidakpuasan pelanggan. Kotler (2004, hal. 36) menyatakan bahwa kepuasan/ketidakpuasan pelanggan adalah respon pelanggan terhadap evaluasi ketidaksesuaian (disconfirmation) yang dirasakan antara harapan sebelumnya (atau norma kinerja lainnya) dan kinerja aktual produk yang dirasakan setelah pemakaiannya.

Dalam dunia perbankan, perkembangan di bidang ilmu pengetahuan dan teknologi juga mempengaruhi aktivitas perbankan terutama dalam segi pemrosesan data elektronik dan telekomunikasi. Bank dapat memilih bentuk dan jenis teknologi yang paling tepat digunakan untuk mencapai tujuan. Hal tersebut akan berpengaruh pada proses keputusan dari segi ketepatan dan akurasinya. Selain teknologi, hal yang sangat vital dalam perbankan adalah kualitas layanan itu sendiri. Kualitas layanan sangat berpengaruh pada loyalitas pelanggan. Layanan yang baik adalah kemampuan perusahaan dalam memberikan layanan dan kepuasan kepada pelanggan dengan standar yang telah ditentukan. Dalam penelitian ini, penulis ingin meneliti beberapa faktor penting di dalam penyediaan kualitas layanan yang tertera dalam dimensi kualitas layanan. Kualitas tidak dapat dipandang sebagai suatu ukuran sempit dari kualitas produk dan jasa semata akan tetapi mencakup keseluruhan aspek organisasi yang berkaitan dengan kepuasan pelanggan.

Menurut Zeithmal \& Berry (dalam Tjiptono, 2005, hal. 133), lima dimensi kualitas layanan meliputi Reliability (kemampuan perusahaan dalam memberikan layanan yang cepat dan dapat diandalkan), Responsiveness (kemampuan merespon atau kesigapan perusahaan dalam membantu pelanggan dan memberikan layanan dengan cepat), Assurance (kemampuan, kesopanan, dan sifat dapat dipercaya yang dimiliki oleh para staf, bebas dari bahaya, risiko dan keraguan), Emphaty (kemudahan dalam melakukan hubungan komunikasi yang baik dan mampu memahami kebutuhan pelanggan), dan Tangible (fasilitas fisik, perlengkapan, penampilan karyawan, dan sarana komunikasi). Untuk 
menciptakan good performance, bank tidak dapat menghindari fungsi layanan nasabah. Layanan yang diberikan kepada nasabahnya akan mencerminkan seberapa baik kualitas layanan bank tersebut. Begitu juga dengan apa yang diharapkan oleh para nasabah Bank Perkreditan Rakyat Bakti Daya Ekonomi (BPR BDE) Pakem Sleman Yogyakarta. Sebagai salah satu bank perkreditan rakyat di Yogyakarta yang memberikan jasa keuangan ritel, BPR BDE mengedepankan kualitas layanan bagi kepuasan nasabahnya. Sebagai salah satu BPR besar di Yogyakarta, BPR BDE selalu berusaha melakukan hal tersebut secara optimal, sehingga dari waktu ke waktu jumlah nasabah BPR BDE Pakem Sleman mengalami peningkatan (Tabel 1).

\begin{tabular}{|c|c|r|}
\hline Tahun & Jumlah Nasabah (orang) & Persentase Kenaikan (\%) \\
\hline 2009 & 5.571 & - \\
\hline 2010 & 5.994 & 7,59 \\
\hline 2011 & 7.981 & 33,14 \\
\hline 2012 & 8.623 & 9,29 \\
\hline \multicolumn{2}{|c|}{ Rata-rata peningkatan } & 16,64 \\
\hline
\end{tabular}

Sumber: www.bprbde.co.id

Batasan masalah yang digunakan dalam penelitian ini adalah:

1. Penelitian berkaitan dengan lima dimensi kualitas layanan pada BPR BDE Pakem Sleman yang mencakup faktor Reliability, Responsiveness, Assurance, Emphaty, dan Tangible.

2. Penelitian dilakukan terhadap nasabah yang sedang melakukan transaksi dan hubungan langsung dengan karyawan bagian layanan BPR BDE Pakem Sleman.

3. Penelitian ini dilakukan pada obyek penelitian BPR BDE Pakem Sleman tahun 2013.

Berdasarkan latar belakang dan batasan masalah di atas, yang menjadi rumusan masalah dalam penelitian ini adalah:

1. Bagaimana tingkat kepuasan nasabah terhadap dimensi kualitas layanan jasa BPR BDE Pakem Sleman Yogyakarta?

2. Atribut dimensi kualitas layanan manakah yang dianggap paling penting oleh nasabah dalam pengambilan keputusan penggunan layanan jasa BPR BDE Pakem Sleman Yogyakarta?

Berdasarkan rumusan masalah yang sudah tertulis di atas,tujuan penelitian ini adalah:

1. Untuk mengetahui tingkat kepuasan nasabah terhadap dimensi kualitas layanan jasa BPR BDE Pakem Sleman Yogyakarta.

2. Untuk mengetahui atribut dimensi layanan jasa manakah yang dianggap paling penting oleh nasabah dalam pengambilan keputusan 
penggunaan layanan jasa BPR BDE Pakem Sleman Yogyakarta.

\section{LANDASAN TEORI}

Pemasaran adalah proses sosial dan manajerial yang di dalamnya individu dan kelompok mendapatkan apa yang mereka butuhkan dan inginkan dengan menciptakan, menawarkan, dan secara bebas mempertukarkan produk yang bernilai dengan pihak lain (Kotler, 2004, hal. 5). Dharmmesta dan Irawan (2005, hal. 179) menyatakan bahwa pemasaran merupakan suatu sistem keseluruhan dari kegiatan-kegiatan bisnis yang ditujukan untuk merencanakan, mempromosikan, dan mendistribusikan barang/jasa untuk memuaskan kebutuhan baik kepada pembeli yang ada maupun pembeli potensial. Dengan kata lain, kegiatan pemasaran bermula dan berakhir pada konsumen. Perusahaan yang berorientasi pada konsumen (pasar) akan memiliki kegiatan pemasaran yang bermula dan berakhir pada diri konsumen. Pemuasan kebutuhan konsumen merupakan hal mutlak yang harus dilakukan bagi kelangsungan hidup perusahaan, yang tercermin dalam konsep pemasaran (Dharmmesta dan Irawan, 2005, hal. 10).

Marketing mix atau bauran pemasaran adalah kombinasi dari empat variabel yaitu produk, struktur harga, kegiatan promosi, dan sistem distribusi (Dharmmesta dan Handoko, 2000, hal. 124). Keempat unsur bauran pemasaran tersebut saling berhubungan dan berpengaruh satu sama lain, sehingga harus diupayakan untuk menghasilkan suatu kebijakan pemasaran yang mengarah kepada layanan efektif dan kepuasan konsumen. Oleh karena itu, perusahaan digabungkan untuk memperoleh tanggapan yang diinginkan di pasar sasaran. Dengan perangkat tersebut perusahaan dapat mempengaruhi permintaan akan produknya. Bauran pemasaran dapat dijabarkan sebagai berikut: 1) Produk. Kotler (2004, hal. 139) menyebutkan produk adalah segala sesuatu yang dapat ditawarkan untuk memuaskan suatu kebutuhan dan keinginan. Menurut Dharmmesta dan Irawan (2005, hal. 165), produk adalah suatu sifat yang kompleks baik yang dapat diraba maupun tidak dapat diraba, termasuk bungkus, warna, prestige perusahaan dan pengecer yang diterima oleh pembeli untuk memuaskan keinginan atau kebutuhannya. 2) Harga. Harga adalah sejumlah uang yang harus dibayarkan oleh pelanggan untuk mendapatkan suatu produk (Kotler dan Amstrong, 2006, hal. 73). Harga merupakan salah satu penentu keberhasilan suatu perusahaan karena harga menentukan seberapa besar keuntungan yang akan diperoleh perusahaan dari penjualan produknya, baik berupa barang maupun jasa. 3) Distribusi. Saluran distribusi sering disebut saluran perdagangan atau saluran pemasaran. Menurut Dharmmesta dan Irawan (2005, hal. 285), saluran distribusi merupakan 
suatu struktur unit organisasi di dalam perusahaan dan di luar perusahaan yang terdiri atas agen, dealer, pedagang besar, dan pengecer melalui nama sebuah komoditi produk atau jasa yang dipasarkan. Perantara pemasaran merupakan lembaga atau individu-individu yang menjalankan kegiatan khusus di bidang distribusi, yaitu perantara pedagang dan perantara agen. 4) Promosi. Menurut Dharmmesta dan Irawan (2005, hal. 349), promosi adalah arus informasi atau persuasi satu arah yang dibuat untuk mengarahkan seseorang atau organisasi kepada tindakan yang menciptakan pertukaran dalam pemasaran. Tujuan utama promosi adalah menginformasikan, mempengaruhi, dan membujuk serta mengingatkan pelanggan sasaran tentang pemasaran dan bauran pemasaran. Dengan memperhatikan hal tersebut di atas, maka dibutuhkan persiapan atau pun sarana promosi agar apa yang diinginkan perusahaan dapat menemui sasaran secara efektif dan efisien. Sarana promosi dapat berupa iklan, promosi penjualan, penjualan personal, publisitas, dan pemasaran langsung.

Menurut Kotler dalam Lupiyoadi (2005, hal. 6), jasa merupakan setiap tindakan atau kegiatan yang ditawarkan oleh salah satu pihak kepada pihak lain. Pada dasarnya, jasa tidak berwujud dan tidak mengakibatkan kepemilikan apa pun. Produksi jasa bisa berkaitan dengan produk fisik atau sebaliknya. Jasa memiliki empat karakteristik, yaitu: 1)Tidak berwujud (intangibility): tidak seperti produk fisik, jasa tidak dapat dilihat, dirasa, diraba, didengar, atau dicium sebelum jasa itu dibeli. 2) Tidak terpisahkan (inseparability): umumnya, jasa dihasilkan dan dikonsumsi secara bersamaan. Jika seseorang menkonsumsi jasa, maka penyediaannya adalah bagian dari jasa tersebut. Karena pelanggan juga hadir saat jasa itu dikonsumsi. Interaksi penyelia dan pelanggan merupakan ciri khusus pemasaran jasa. 3) Bervariasi (variability): jasa itu sangat bervariasi karena tergantung pada siapa yang menyediakan dan di mana jasa itu diberikan. 4) Mudah hilang (perishability): jasa tidak bisa disimpan. Mudah hilangnya jasa tidak menjadi masalah apabila permintaan tetap karena mudah untuk terlebih dahulu mengatur staf untuk melakukan jasa itu bila permintaan berfluktuasi.

Layanan merupakan kunci sukses sebuah perusahaan. Kualitas harus meliputi keseluruhan aspek dalam organisasi bisnis. Zeithmal dan Berry (dalam Tjiptono, 2006, hal. 133) mengemukakan adanya lima dimensi yang menentukan kualitas layanan (service quality) ditinjau dari sudut pandang pelanggan, yaitu: 1)Reliability yaitu kemampuan perusahaan dalam memberikan jasa yang tepat dan dapat diandalkan. 2) Responsiveness yaitu kemampuan merespon atau kesigapan perusahaan dalam membantu pelanggan dan memberikan layanan dengan cepat. 3) Assurance yaitu jaminan dan sifat dapat dipercaya yang dimiliki oleh para staf perusahaan, bebas dari bahaya, risiko, dan keraguan. 4) Emphaty yaitu kemudahan dalam melakukan hubungan komunikasi yang baik dan 
memahami kebutuhan pelanggan. 5) Tangible yaitu fasilitas fisik, perlengkapan, penampilan karyawan, dan sarana prasarana komunikasi.

Dimensi kualitas jasa tersebut berpengaruh pada harapan nasabah dan kenyataan yang mereka terima. Jika kenyataannya nasabah menerima layanan melebihi harapannya, maka nasabah akan mengatakan layanannya berkualitas. Sebaliknya, jika kenyataannya nasabah menerima layanan kurang atau sama dari harapannya, maka nasabah akan mengatakan layanannya tidak berkualitas atau tidak memuaskan.

Perilaku konsumen (consumer behavior) adalah kegiatan-kegiatan individu yang secara langsung terlibat dalam mendapatkan dan mempergunakan barang atau jasa yang di dalamnya terdapat proses pengambilan keputusan pada persiapan dan penentuan untuk memutuskan pilihan (Dharmmesta dan Handoko, 2000, hal. 10). Dalam hubungan dengan keputusan pembelian suatu produk atau jasa, pemahaman mengenai perilaku konsumen meliputi jawaban atas pertanyaan seperti: apa (what) yang dibeli, di mana membeli (where), bagaimana kebiasaan (how often) membeli, dan dalam keadaan apa (under what conditions) barang dan jasa yang dibeli tersebut.

Model perilaku konsumen (Kotler, 2004, hal. 222) menerangkan bahwa keputusan konsumen dalam pembelian selain dipengaruhi oleh karakteristik konsumen, dapat dipengaruhi juga oleh rangsangan perusahaan yang mencakup produk, harga, distribusi, dan promosi. Variabel-variabel tersebut saling mempengaruhi proses keputusan pembelian sehingga menghasilkan keputusan pembelian yang didasarkan

\begin{tabular}{|l|l|c|}
\hline 2. Marketing & \multicolumn{1}{|c|}{ Konsumen } & \multicolumn{1}{|c|}{ Respon Konsumen } \\
1. Karakteristik pembeli & $\begin{array}{l}\text { 1. Pilihan produk } \\
\text { 2. Pilihan merk }\end{array}$ \\
$\begin{array}{l}\text { 3. Pilihan tempat } \\
\text { pembelian } \\
\text { 2. Waktu dan jumlah } \\
\text { pembelian }\end{array}$ \\
2. Proses pengambilan \\
keputusan pembelian
\end{tabular}

Sumber: Sudarmiatin, 2009, hal. 4.

Gambar 1

Bagan Model Perilaku Konsumen

Model perilaku konsumen pada Gambar 1 di atas dikembangkan oleh Assael (dalam Sudarmiatin, 2009, hal. 4) yang menyebutkan bahwa proses keputusan konsumen dalam pembelian ditekankan pada tiga faktor antara lain: a) Stimuli menunjukkan penerimaan informasi oleh konsumen dan pemprosesan informasi terjadi saat konsumen 
mengevaluasi informasi dari periklanan, teman atau pengalaman sendiri. b) Karakteristik pribadi konsumen meliputi persepsi, sikap, manfaat serta karakteristik konsumen (demografi, kepribadian, gaya hidup) c) Respon konsumen adalah hasil akhir dari proses keputusan konsumen dan suatu pertimbangan yang menyeluruh dari semua faktor di atas.

Bagi dunia perbankan yang merupakan badan usaha yang berorientasi pada profit, kegiatan pemasaran sudah merupakan suatu kebutuhan utama dan sudah merupakan suatu keharusan untuk dijalankan. Pengelolaan pemasaran bank yang profesional inilah yang disebut dengan manajemen pemasaran bank. Kasmir (2004, hal. 63) menyatakan bahwa pemasaran bank adalah suatu proses untuk menciptakan dan mempertukarkan produk atau jasa bank yang ditujukan untuk memenuhi kebutuhan dan keingin an nasabah dengan cara memberikan kepuasan. Dari definisi tersebut, beberapa pengertian yang perlu diketahui adalah: 1) Produk bank adalah jasa yang ditawarkan kepada nasabah untuk mendapatkan perhatian, untuk dimiliki, digunakan, atau dikonsumsi untuk memenuhi kebutuhan dan keinginan nasabah. Produk bank terdiri atas produk simpanan (giro, tabungan, dan deposito), pinjaman (kredit), serta jasa-jasa bank lainnya seperti transfer, kliring, inkaso, safe deposit box, kartu kredit, letter of credit, bank garansi, traveller cheque, bank draft, dan jasa-jasa bank lainnya. 2) Permintaan adalah suatu keinginan manusia yang didukung oleh daya belinya. Permintaan akan terjadi apabila konsumen memiliki sejumlah dana atau barang pengganti untuk memperoleh barang yang lain. Besarnya permintaan nasabah tergantung dari daya beli nasabah tersebut, di samping harus didukung oleh minat dan akses untuk mendapatkannya. 3)Pertukaran adalah tindakan untuk memperoleh suatu barang atau jasa yang diinginkan dari seseorang dengan menawarkan sesuatu sebagai penggantinya. 4) Pasar adalah kumpulan nasabah (pembeli nyata dan pembeli potensial) atas suatu produk, baik barang maupun jasa. Pasar dapat diartikan pula sebagai tempat penjual dan pembeli melakukan transaksi. Di samping itu, pasar tidak selalu memiliki tempat pertemuan, tetapi dapat berupa alat-alat lain seperti telepon, faks, dan internet. 5) Kebutuhan nasabah bank adalah suatu keadaan yang dirasakan ada dalam diri seseorang. 6) Keinginan nasabah bank merupakan kebutuhan yang dibentuk oleh kultur dan kepribadian individu.

Menurut Kasmir (2004, hal. 66), tujuan pemasaran bank secara umum adalah: 1)Memaksimumkan konsumsi atau dengan kata lain memudahkan dan merangsang konsumsi, sehingga dapat menarik nasabah untuk membeli produk yang ditawarkan bank secara berulangulang. 2) Memaksimumkan kepuasan pelanggan melalui berbagai layanan yang diinginkan nasabah. Nasabah yang puas akan menjadi ujung tombak pemasaran selanjutnya, karena kepuasan ini akan 
ditularkan kepada nasabah lainnya melalui ceritanya (word of mouth). 3) Memaksimumkan pilihan ragam produk dalam arti bank menyediakan berbagai jenis produk bank sehingga nasabah memiliki beragam pilihan pula. 4) Memaksimumkan mutu hidup dengan memberikan berbagai kemudahan kepada nasabah dan menciptakan iklim yang efisien.

Kotler (2004, hal. 146) mengatakan bahwa kepuasan konsumen merupakan tingkat perasaan seseorang setelah membandingkan antara kinerja produk yang ia rasakan dengan harapannya. Kepuasan atau ketidakpuasan konsumen adalah respon terhadap evaluasi ketidaksesuaian atau diskonfirmasi yang dirasakan antara harapan sebelumnya dan kinerja aktual produk yang dirasakan setelah pemakaian. Menurut Rangkuti (2002, hal. 30) kepuasan konsumen merupakan respon pelanggan terhadap ketidaksesuaian antara tingkat kepentingan sebelumnya dan kinerja aktual yang dirasakannya setelah pemakaian. Kepuasan pelanggan dipengaruhi oleh persepsi kualitas jasa, kualitas produk, harga dan faktor-faktor yang bersifat pribadi serta yang bersifat situasi sesaat.

Dalam sebuah penelitian sejenis sebelumnya, tesis berjudul Analisis Kualitas Layanan terhadap Kepuasan Nasabah PT. Bank Jateng Cabang Purworejo (Hartono, 2005, hal. 56-68) terdapat hasil temuan-temuan yang sangat mendukung penelitian ini. Temuan-temuan dalam penelitian ini terbukti mendukung teori-teori Garpersz (1997) yang menyatakan atribut kualitas layanan adalah ketepatan/kecepatan layanan, akurasi layanan, dan kenyamanan yang dapat dimasukkan dalam variabel reliability, responsiveness, assurance, emphaty, dan tangible. Penelitian ini juga mendukung teori Zeithmal dkk. (1990) bahwa tolok ukur kualitas layanan dapat diukur oleh sepuluh subvariabel (dimensi), yaitu: tangible (berwujud), reliability (keandalan), responsiveness (keresponsifan), competence (pengetahuan dan ketrampilan), courtesy (perilaku), credibility (kejujuran), security (keamanan), access (kemudahan hubungan), communications (komunikasi), dan understanding the customer (mengerti kebutuhan masyarakat) yang dapat diringkas menjadi lima variabel di atas.

Variabel Reliability, Responsiveness, Assurance, Emphaty, dan Tangible berpengaruh positif terhadap kepuasan nasabah. Variabel yang mempunyai pengaruh lebih dominan terhadap kepuasan nasabah adalah tangible, maka wujud nyata dari PT. Bank Jateng Cabang Purworejo harus menjadi perhatian utama bagi pimpinan dan direksi. Penelitian ini juga menunjang teori Lewis dan Booms (1983) (dalam Tjiptono dan Chandra, 2005, hal. 121) yang menyatakan kualitas jasa sebagai ukuran seberapa bagus tingkat layanan yang diberikan sesuai dengan ekspektasi/harapan pelanggan/nasabah. Penelitian ini mendukung penelitian Host (2004) (dalam Agung dkk., 2005, hal. 10) yang 
menyatakan ada hubungan antara kepuasan pelanggan dan kualitas layanan yang indikatornya adalah tangible, reliability, responsiveness, assurance, dan emphaty. Dalam penelitian ini, kelima variabel bebas (reliability, responsiveness, assurance, emphaty, dan tangible) mempunyai pengaruh positif dan signifikan terhadap kepuasan nasabah PT. Bank Jateng Cabang Purworejo.

\section{KERANGKA PIKIR PENELITIAN}

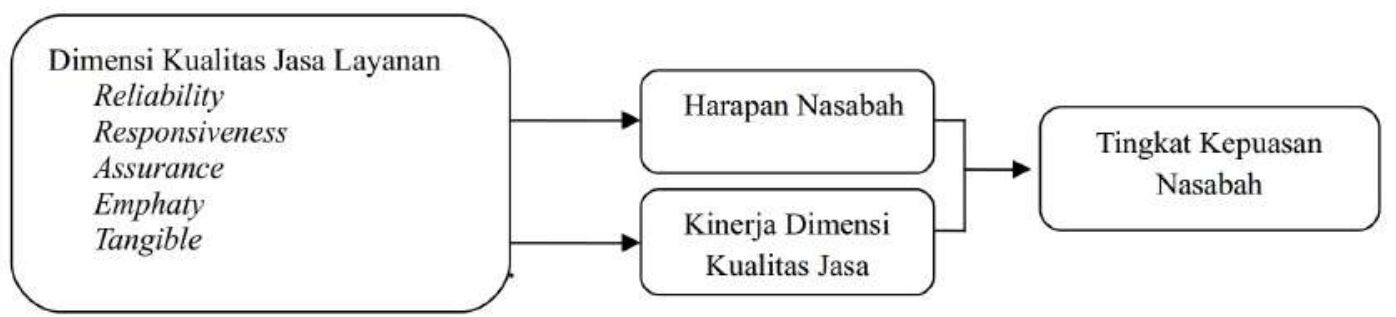

Sumber: Tjiptono, 2005, hal. 273.

Gambar 2

Kerangka Pikir Penelitian

Menurut Tjiptono, 2006, hal. 133, tingkat kepuasan nasabah dapat dipahami dengan meneliti lima dimensi kualitas layanan yaitu Reliability (kemampuan perusahaan dalam memberikan layanan yang cepat dan dapat diandalkan), Responsiveness (kemampuan merespon atau kesigapan perusahaan dalam membantu pelanggan dan memberikan layanan dengan cepat), Assurance (kemampuan, kesopanan, dan sifat dapat dipercaya yang dimiliki oleh para staf, bebas dari bahaya, risiko, dan keraguan), Emphaty (kemampuan dalam melakukan hubungan komunikasi yang baik dan memahami kebutuhan pelanggan), Tangible (fasilitas fisik, perlengkapan, penampilan karyawan dan sarana komunikasi). Dimensi kualitas tersebut dijadikan dasar untuk mengetahui apakah ada kesenjangan atau perbedaan antara harapan konsumen dan kenyataan atau kinerja yang mereka terima.

\section{METODE PENELITIAN}

\section{Disain Penelitian}

Penelitian ini dilaksanakan pada obyek penelitian Bank Perkreditan Rakyat Bakti Daya Ekonomi (BPR BDE) yang terletak di di Pakem Sleman Yogyakarta. Variabel-variabel penelitian pada setiap dimensi kualitas layanan yang disusun berdasarkan penelitian Dahlan (2009, hal. 37-38) 
sebagai berikut:

1. Reliability adalah kemampuan perusahaan dalam memberikan jasa yang tepat dan dapat diandalkan. Indikator variabel reliability adalah:

a) Ketepatan waktu layanan; b) Profesionalisme layanan; c) Ketepatan dan ketelitian dalam memberikan layanan; d) Kemudahan dan ketepatan prosedur layanan.

2. Responsiveness adalah kemampuan merespon atau kesigapan perusahaan dalam membantu dan memberikan layanan kepada pelanggan dengan cepat. Indikator variabel responsiveness adalah: a) Kesigapan karyawan dalam membantu keperluan atau informasi yang dibutuhkan oleh nasabah; b)Kesanggupan mengubah layanan sesuai kebutuhan nasabah; c) Kesigapan karyawan dalam menangani dan menyelesaikan keluhan nasabah; d)Tindakan layanan yang cepat pada saat nasabah membutuhkan bantuan dengan penanganan yang tepat.

3. Assurance yaitu kemampuan bersikap sopan dan sifat dapat dipercaya yang dimiliki oleh para staf, bebas dari bahaya, risiko dan keraguan. Indikator variabel assurance adalah: a)Pengetahuan dan keakuratan informasi yang disampaikan kepada nasabah; b) Kemampuan karyawan dalam memberikan layanan sesuai janji yang telah diberikan c)Kepercayaan terhadap bank; d) Keamanan bertransaksi.

4. Emphaty yaitu kemampuan dalam melakukan hubungan komunikasi yang baik dan memahami kebutuhan pelanggan. Variabel emphaty indikatornya adalah: a) Kemampuan karyawan berkomunikas; b) Perhatian karyawan secara personal; c) Layanan kepada nasabah tanpa memandang status sosial; d) Kemudahan untuk dihubungi oleh nasabah.

5. Tangible yaitu wujud fasilitas fisik, perlengkapan, penampilan karyawan, dan sarana komunikasi. Indikator variabel tangible antara lain: a) Penampilan dan kerapian seragam karyawan; b) Penampilan fisik gedung; c) Ketersediaan dan kelayakan tempat parkir; d) Kemudahan akses menjangkau lokasi bank.

\section{Pengukuran Variabel Penelitian}

Variabel-variabel dalam penelitian ini diukur menggunakan skala ordinal. Metode pengukuran yang digunakan adalah skala Likert (Umar, 2011, hal. 70). Skala Likert ini berhubungan dengan pernyataan tentang sikap seseorang terhadap sesuatu yang merupakan suatu kontinum, misalnya antara setuju-tidak setuju, senang-tidak senang, dan baik-tidak baik. Responden diminta mengisi pernyataan dalam skala ordinal berbentuk verbal dalam jumlah kategori tertentu. Skala Likert yang digunakan adalah skala dengan lima tingkatan. Alasan pemilihan skala lima tingkatan ini adalah kesesuaian dengan penelitian sebelumnya, 
memperbesar variasi jawaban bila dibandingkan dengan empat skala, dan agar terlihat kecenderungan pemilihan responden terhadap variabel. Masing-masing alternatif jawaban diberikan skor numerik sebagai berikut: sangat tidak setuju (1), tidak setuju (2), tidak yakin (3), setuju (4), sangat setuju (5).

\section{Populasi dan Sampel}

Populasi ialah suatu himpunan unit yang biasanya berupa orang, obyek, transaksi, kegiatan, dan kejadian yang akan dipelajari (Kuncoro, 2001, hal. 103). Populasi dalam penelitian ini adalah seluruh nasabah BPR BDE Pakem Sleman Yogyakarta. Sampel adalah bagian dari jumlah karakteristik yang dimiliki oleh sebuah populasi (Kuncoro,2001, hal. 103). Sampel adalah bagian dari populasi untuk dijadikan sebagai bahan penelaahan dengan harapan bagian atau contoh yang diambil dari populasi tersebut dapat mewakili atau representatif terhadap populasinya, yaitu nasabah BPR BDE Pakem Sleman yang sedang melakukan transaksi dan berhubungan langsung dengan karyawan.

Pengambilan sampel dalam penelitian ini dilakukan dengan menggunakan metode nonprobability sampling, dengan teknik purposive sampling (Sekaran, 2006, hal. 136), yaitu pengambilan sampel yang tidak memberi peluang atau kesempatan yang sama bagi setiap unsur populasi untuk dipilih menjadi sampel. Sampel yang diambil harus terlebih dulu diketahui bahwa sampel tersebut sesuai dengan disain penelitian yang telah disusun oleh peneliti yang akan dijadikan sampel dan diperlukan dalam penelitian ini. Dengan kata lain, karakteristik sampel harus sesuai dengan yang dibutuhkan oleh peneliti. Karakteristik tersebut secara spesifik antara lain responden adalah nasabah yang telah tercatat sebagai konsumen di BPR BDE Pakem Sleman dan sedang melakukan transaksi atau berhubungan langsung dengan karyawan pada saat pengumpulan data dilakukan. Jumlah sampel dalam penelitian ditentukan berdasarkan rumus Slovin yang dikutip oleh Umar (2011, hal. 78) adalah sebagai berikut:

$$
n=\frac{N}{1+N(e)^{2}}
$$

Keterangan:

$\mathrm{n}$ = Ukuran Sampel.

$\mathrm{N}=$ Ukuran populasi, yaitu jumlah total pelanggan/nasabah yang menggunakan jasa BPR BDE Pakem Sleman tahun 2012.

$\mathrm{e}=$ Nilai Kritis. 
Dalam penelitian ini diketahui bahwa jumlah populasi $(\mathrm{N})$ sebanyak 8.623 nasabah (2012), dengan nilai kritis atau batas toleransi kesalahan penelitian yang ditentukan peneliti sebesar 10\%, maka besar ukuran sampel (n) dapat ditentukan sebagai berikut:

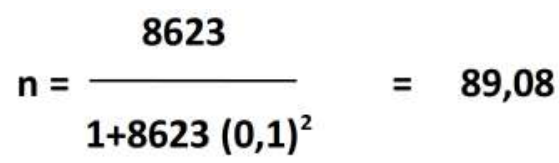

Berdasarkan perhitungan di atas didapatkan hasil ukuran sampel sebanyak 89,08 . Untuk kepentingan penelitian ini, jumlah ukuran sampel ditetapkan dengan pembulatan menjadi 100 orang nasabah BPR BDE Pakem Sleman Yogyakarta.

\section{Metode Pengumpulan Data}

Metode pengumpulan data yang digunakan pada penelitian ini adalah survei melalui penggunaan teknik pengumpulan data dengan kuesioner dan studi dokumentasi.

1. Kuesioner yaitu sekumpulan pertanyaan atau pernyataan tertulis yang telah disusun sedemikian rupa menjadi sebuah instrumen penelitian dan disebarkan kepada responden yang telah ditentukan untuk dijawab (Sugiyono, 2004, hal. 162).

2. Studi Dokumentasi. Dokumentasi merupakan suatu teknik pengumpulan data dengan menghimpun dan menganalisis dokumendokumen, baik dokumen tertulis, gambar maupun elektronik. Dokumen yang telah diperoleh kemudian dianalisis (diurai), dibandingkan, dan dipadukan untuk membentuk satu hasil kajian yang sistematis, terpadu, dan utuh.

\section{Uji Instrumen Penelitian}

Instrumen penelitian dikatakan baik jika instrumen secara tepat mewakili apa yang dimaksudkan oleh peneliti serta konsisten hasilnya saat digunakan berkali-kali. Pengujian instumen terdiri atas uji validitas dan reliabilitas.

1. Uji Validitas

Validitas adalah tingkat keandalan dan kesahihan alat ukur yang digunakan. Intrumen dikatakan valid berarti menunjukkan alat ukur yang dipergunakan untuk mendapatkan data itu valid atau dapat digunakan untuk mengukur apa yang seharusnya diukur (Umar, 2005, hal. 179). Instrumen yang valid merupakan instrumen yang benar-benar tepat untuk mengukur apa yang hendak diukur. Uji validitas untuk mengetahui apakah ada pernyataan-pernyataan pada 
kuesioner yang harus dibuang/diganti karena dianggap tidak relevan. Cara untuk mengukur validitas kuesioner adalah dengan menghitung korelasi antar data pada masing-masing pernyataan dengan skor total dengan memakai rumus korelasi Pearson product's moment. Item pertanyaan dalam instrumen dianggap valid jika angka koefisien korelasi lebih besar dari 0,3 atau bisa juga dengan membandingkannya dengan $\mathrm{r}$ tabel. Jika $\mathrm{r}$ hitung $>\mathrm{r}$ tabel maka instrumen penelitian dianggap valid (Sekaran, 2006, hal. 44).

Uji validitas dilakukan dengan menghitung korelasi antara masingmasing pernyataan dengan skor total seluruh pernyataan pada kuesioner instrumen pengumpulan data penelitian. Penghitungan uji validitas menggunakan bantuan program SPSS (Statistical Package for Social Science) 16.0. Hasil perhitungan uji validitas dalam penelitian ini menunjukkan bahwa seluruh item pernyataan memiliki nilai koefisien Pearson Product Moment lebih besar dari 0,3 sehingga dapat disimpulkan bahwa seluruh item pernyataan adalah valid. Pengujian ini didasarkan pada tingkat signifikansi 0,01 atau $1 \%$ dan 0,05 atau $5 \%$ pada pengujian dua ekor. Seluruh butir pernyataan pada semua kelompok memiliki nilai koefisien Pearson Product Moment yang lebih besar dari 0,3 (Reliabilty $=0,572 ;$ Responsiveness $=0,511$; Assurance $=$ 0,569; Emphaty = 0,605; Tangible $,=0,507)$, sehingga dapat disimpulkan seluruh item pernyataan tersebut adalah valid.

2. Uji Reliabilitas

Uji reliabilitas berguna untuk menetapkan apakah instrumen kuesioner dapat digunakan lebih dari satu kali atau paling tidak oleh responden yang sama akan menghasilkan data yang konsisten. Dengan kata lain, reliabilitas instrumen mencirikan tingkat konsistensi (Umar, 2005, hal. 194). Pengujian reliabilitas menggunakan metode Cronbach Alpha. Standar untuk mengetahui sebuah instrumen reliabel atau tidak adalah dengan melihat nilai alpha hasil perhitungan uji. Apabila nilai alpha hitung lebih besar atau sama dengan 0,6 dan positif, maka suatu instrumen penelitian dapat dikatakan reliabel (Sekaran, 2006, hal. 42). Hasil perhitungan uji reliabilitas menunjukkan bahwa seluruh item pernyataan pada kelompok pernyataan Tingkat Pengaruh Dimensi Kualitas Jasa, memiliki nilai Nilai Cronbach Alpha = 0,606 atau lebih besar dari 0,6, sehingga dapat disimpulkan seluruh item pernyataan valid.

\section{Data Karakteristik Responden}

Berdasar hasil penelitian dapat diidentifikasi karakteristik responden BPR BDE Pakem Sleman berdasarkan tujuh karakteristik yaitu, jenis kelamin, umur, pendidikan terakhir, pekerjaan, penghasilan per bulan, 
lama menjadi nasabah, dan frekuensi melakukan transaksi dalam enam bulan terakhir. Dari hasil penelitian yang telah dilakukan, responden dalam penelitian ini sebagian besar adalah laki-laki yaitu sebanyak 61 responden atau $61 \%$ dan perempuan sebanyak 39 responden atau 39\%. Responden dalam penelitian ini sebagian besar berusia antara 31-45 tahun yaitu 56\% dan sebagian kecil berusia kurang dari 17 tahun yaitu 4\%. Responden yang berusia antara 17-30 tahun sebanyak 29\% dan responden yang berusia lebih dari 45 tahun adalah 11\%.

Responden dalam penelitian ini sebagian besar berlatar belakang pendidikan SMP yaitu sebanyak 38\% dari jumlah responden yang diteliti. Responden dengan latar belakang pendidikan SD sebanyak $12 \%$, diploma atau sarjana sebanyak $10 \%$, dan pascasarjana sebanyak $4 \%$. Berdasarkan hasil tersebut dapat disimpulkan bahwa nasabah yang menggunakan jasa BPR BDE Pakem Sleman sebagian besar adalah berlatar belakang pendidikan SD dan SMP, yang sesuai dengan segmen pasar bank yaitu masyarakat pedesaan dan masyarakat yang bergerak dalam usaha kecil dan mikro. Responden dalam penelitian ini sebagian besar bekerja sebagai karyawan swasta yaitu sebanyak 32\%, wiraswasta 29\%, PNS/TNI/POLRI 14\%, sedangkan nasabah yang berstatus sebagai pelajar/mahasiswa sebanyak 11\%. Sisanya sebanyak $14 \%$ memiliki pekerjaan lain-lain seperti petani, pensiunan, dan pedagang.

Sebagian besar responden berpenghasilan antara Rp1.500.001Rp3.000.000 yaitu sebanyak 40\%. Responden yang berpenghasilan kurang dari Rp1.000.000 sebanyak 25\%, yang berpenghasilan Rp1.000.001Rp1.500.000 sebanyak 20\%, sedangkan responden yang berpenghasilan lebih dari Rp3.000.000 sebanyak 15\%. Sebagian besar responden dalam penelitian ini telah menjadi nasabah selama enam bulan sampai dua tahun sebanyak 66\%, sebagian kecil responden menjadi nasabah kurang dari enam bulan sebanyak $2 \%$. Responden dalam penelitian ini melakukan transaksi lebih dari enam kali dalam kurun waktu enam bulan terakhir yaitu 67\%, sedangkan yang melakukan transaksi kurang dari enam kali dalam kurun waktu yang sama sebanyak 33\% dari seluruh responden.

\section{ANALISIS DATA PENELITIAN}

Analisis data dalam penelitian ini menggunakan dua macam analisis yang sudah disebutkan dalam bab sebelumnya yaitu Analisis Nilai RataRata Dimensi Kualitas Jasa (Mean Arithmathic) dan Analisis Tingkat Kepentingan-Kinerja Dimensi Kualitas Jasa (Importance-Performance Analysis) yang di dalamnya terdapat analisis Diagram Kartesius. 


\section{Analisis Mean Arithmathic}

Adapun rata-rata tingkat kepentingan maupun tingkat kualitas dimensi layanan tersebut diperoleh dengan perhitungan rerata hitung (mean aritmathic), yaitu dengan menjumlahkan seluruh data dibagi dengan banyaknya data (Sugiyono, 2012, hal. 49), dengan rumus matematis sebagai berikut:

$$
X=\frac{\sum X i}{n}
$$

Keterangan:

$\mathrm{X}=$ Rata-rata tingkat kepentingan/kualitas atribut

$\sum \mathrm{Xi} \quad=$ Jumlah seluruh nilai skor dalam sampel

$\mathrm{n} \quad=$ Jumlah sampel

Nilai rata-rata tingkat kepentingan pada setiap dimensi kualitas jasa yang diperoleh dari perhitungan tersebut selanjutnya dikategorisasi dalam rentang skala kategori sebagai berikut (Tabel 2):

Tabel 2

Pengkategorian Rerata Tingkat Harapan/Kinerja

\begin{tabular}{|c|c|}
\hline Rentang Skala & Kategori \\
\hline $1,00 \leq X \leq 1,80$ & Sangat tidak Berpengaruh \\
\hline $1,81 \leq X \leq 2,60$ & Tidak Berpengaruh \\
\hline $2,61 \leq X \leq 3,40$ & Cukup Berpengaruh \\
\hline $3,41 \leq X \leq 4,20$ & Berpengaruh \\
\hline $4,21 \leq X \leq 5,00$ & Sangat Berpengaruh \\
\hline
\end{tabular}

Sumber: Simamora, 2004, Riset Pemasaran Falsafah, Teori dan Aplikasi, hal. 59.

Besarnya jarak rentang skala untuk pengkategorian tersebut diperoleh berdasarkan perhitungan sebagai berikut:

$$
\begin{aligned}
& \text { Rentang Skala }=\frac{\text { Nilai Maks Skala Likert }- \text { Nilai Min Skala Likert }}{\text { Jumlah Kelas dalam Skala Likert }} \\
& \text { Rentang Skala }=(5-1): 5=0,8
\end{aligned}
$$

Rentang skala rerata tingkat kepentingan dan tingkat kualitas jasa pada setiap kategori memiliki jarak 0,8 (Supranto, 2001, hal. 63).

Berikut ini diuraikan analisis rata-rata tingkat pengaruh dimensi kualitas jasa layanan perbankan terhadap nasabah dalam mengambil 
keputusan untuk menggunakan jasa layanan tersebut. Hasil perhitungan data dengan menggunakan rerata hitung (mean arithmathic) diperoleh hasil seperti yang terlihat pada Tabel 3 berikut ini.

Berdasarkan Tabel 3 di atas dapat ditunjukkan bahwa:

a. Dimensi Reliability (keandalan) dengan skor rata-rata 4,19 sesuai dengan kelas interval/rentang skala diatas menunjukkan bahwa ratarata nasabah menganggap bahwa dimensi kualitas jasa reliability adalah berpengaruh terhadap keputusan nasabah untuk menggunakan jasa layanan BPR BDE Pakem Sleman.

b. Dimensi Responsiveness (daya tanggap) dengan skor rata-rata 4,27 sesuai dengan kelas interval/rentang skala diatas menunjukkan ratarata nasabah menganggap bahwa dimensi responsiveness dalam jasa layanan adalah sangat berpengaruh terhadap keputusan nasabah untuk menggunakan jasa layanan BPR BDE Pakem Sleman.

c. Dimensi Assurance (jaminan) dengan skor rata-rata 4,07 sesuai dengan kelas interval/rentang skala diatas menunjukkan bahwa rata-rata nasabah menganggap dimensi assurance dalam jasa layanan bank adalah berpengaruh terhadap keputusan nasabah untuk menggunakan jasa layanan BPR BDE Pakem Sleman.

d. Dimensi Emphaty (empati) dengan skor rata-rata 4,43 sesuai dengan kelas interval/rentang skala diatas menunjukkan rata-rata nasabah menganggap bahwa dimensi emphaty dalam jasa layanan adalah sangat berpengaruh terhadap keptusan nasabah untuk menggunakan jasa layanan BPR BDE Pakem Sleman.

e. Dimensi Tangible (wujud fisik) dengan skor rata-rata 4,12 sesuai dengan kelas interval/rentang skala diatas menunjukkan rata-rata nasabah menganggap bahwa tangible atau wujud fisik Bank BPR BDE Pakem Yogyakarta adalah berpengaruh terhadap keputusan nasabah untuk menggunakan jasa layanan BPR BDE Pakem Sleman.

Tabel 3

Hasil Perhitungan Rerata Tingkat Pengaruh

Dimensi Kualitas Jasa BPR BDE Pakem Sleman

\begin{tabular}{|c|c|c|c|c|c|c|c|c|c|}
\hline \multirow{2}{*}{ Dimensi } & \multirow{2}{*}{$\mathbf{N}$} & \multicolumn{5}{|c|}{ Skor jawaban } & \multirow{2}{*}{$\begin{array}{l}\text { Total } \\
\text { Skor }\end{array}$} & \multirow{2}{*}{$\begin{array}{l}\text { Rata- } \\
\text { rata }\end{array}$} & \multirow[t]{2}{*}{ Kategori } \\
\hline & & 1 & 2 & 3 & 4 & 5 & & & \\
\hline Reliability & 100 & 0 & 0 & 2 & 77 & 21 & 419 & 4,19 & Berpengaruh \\
\hline Responsiveness & 100 & 0 & 0 & 18 & 37 & 45 & 427 & 4,27 & Sangat berpengaruh \\
\hline Assurance & 100 & 0 & 0 & 20 & 53 & 27 & 407 & 4,07 & Berpengaruh \\
\hline Emphaty & 100 & 0 & 0 & 14 & 29 & 57 & 443 & 4,43 & Sangat berpengaruh \\
\hline Tangible & 100 & 0 & 6 & 18 & 34 & 42 & 412 & 4,12 & Berpengaruh \\
\hline \multicolumn{8}{|c|}{ Rerata dari rata-rata } & 4,22 & Sangat berpengaruh \\
\hline
\end{tabular}

Sumber: Hasil olah data penelitian, 2014. 
Keterangan kategori (Simamora, 2004, hal. 59):

$1,00 \leq X \leq 1,80$ = Sangat Tidak Berpengaruh $1,81 \leq X \leq 2,60=$ Tidak Berpengaruh

$2,61 \leq X \leq 3,40=$ Cukup Berpengaruh $\quad 3,41 \leq X \leq 4,20=$ Berpengaruh

$4,21 \leq X \leq 5,00=$ Sangat Berpengaruh

Secara umum dapat dijelaskan bahwa, berdasarkan tingkat pengaruh terhadap keputusan nasabah dalam memutuskan untuk menggunakan jasa perbankan, seluruh dimensi kualitas jasa layanan perbankan sangat berpengaruh terhadap nasabah dalam mengambil keputusan untuk menggunakan jasa layanan BPR BDE Pakem Sleman, dengan nilai rerata dari rata-rata sebesar 4,22 sesuai dengan kelas interval/rentang skala menunjukkan sangat berpengaruh. Berdasarkan hasil perhitungan di atas dapat diketahui pula bahwa dimensi emphaty yang meliputi unsur komunikasi yang baik, perhatian, layanan nasabah, dan kemudahan untuk dihubungi adalah dimensi kualitas jasa yang paling berpengaruh terhadap keputusan nasabah, dengan nilai rata-rata sebesar 4,43 sesuai dengan kelas interval/rentang skala menunjukkan sangat berpengaruh, sedangkan dimensi assurance yang meliputi unsur keakuratan informasi, pemenuhan janji, kepercayaan terhadap bank, keamanan bertransaksi adalah dimensi kualitas jasa yang paling kecil tingkat pengaruhnya terhadap keputusan nasabah dengan rata-rata sebesar 4,07 sesuai dengan kelas interval/rentang skala menunjukkan berpengaruh.

Tabel 4

Hasil Perhitungan Nilai Rerata Tingkat Harapan

\begin{tabular}{|c|l|c|c|}
\hline No & \multicolumn{1}{|c|}{ Dimensi Kualitas Jasa } & Nilai Rerata & Kategori \\
\hline \hline 1 & Reliability & 4,15 & Berpengaruh \\
\hline 2 & Responsiveness & 3,96 & Berpengaruh \\
\hline 3 & Assurance & 4,21 & Sangat Berpengaruh \\
\hline 4 & Emphaty & 3,94 & Berpengaruh \\
\hline 5 & Tangible & 3,82 & Berpengaruh \\
\hline \multicolumn{2}{r|}{ Rerata dari rata-rata } & $\mathbf{4 , 0 2}$ & Berpengaruh \\
\hline
\end{tabular}

Sumber: Hasil olah data penelitian, 2014.

Keterangan kategori (Simamora, 2004, hal. 59):

$1,00 \leq X \leq 1,80$ = Sangat Tidak Berpengaruh $1,81 \leq X \leq 2,60=$ Tidak Berpengaruh

$2,61 \leq X \leq 3,40=$ Cukup Berpengaruh $\quad 3,41 \leq X \leq 4,20=$ Berpengaruh

$4,21 \leq X \leq 5,00=$ Sangat Berpengaruh

Analisis berikut ini bertujuan untuk menentukan nilai rerata tingkat harapan dimensi kualitas jasa layanan perbankan, yang akan diketahui seberapa besar harapan nasabah terhadap masing-masing dimensi kualitas layanan jasa perbankan pada BPR BDE Pakem Sleman. Berdasarkan hasil perhitungan data yang terkumpul dari instrumen penelitian kuesioner, yang terdapat dalam Tabel 4 di atas dapat dilihat 
bahwa nilai rerata tingkat kepentingan atau harapan terhadap dimensi kualitas layanan jasa perbankan pada BPR BDE Pakem Sleman secara umum adalah penting dengan nilai rerata 4,02 sesuai dengan kelas interval/rentang skala menunjukkan berpengaruh, sehingga dapat dikatakan bahwa seluruh dimensi kualitas jasa layanan BPR BDE Pakem Sleman menurut nasabah adalah berpengaruh.

Nilai rata-rata tingkat kepentingan dan kategorinya untuk setiap unsur dapat dilihat pada Tabel 7 berikut. Informasi yang disajikan dapat diartikan bahwa unsur kualitas layanan dengan harapan yang paling besar dari nasabah atau tingkat kepentingan paling tinggi menurut nasabah adalah unsur kemudahan dan ketepatan prosedur layanan, dengan koefisien rata-rata 4,42 (Tabel 5), sedangkan harapan/tingkat kepentingan unsur kualitas jasa layanan paling rendah adalah ketersediaan tempat parkir, dengan koefisien rata-rata 3,62 sesuai dengan kelas interval/rentang skala menunjukkan berpengaruh. Nilai rata-rata tingkat kepentingan dan kategorinya untuk setiap unsur dapat dilihat pada Tabel 5 berikut. Informasi yang disajikan dapat diartikan bahwa unsur kualitas layanan dengan harapan yang paling besar dari nasabah atau tingkat kepentingan paling tinggi menurut nasabah adalah unsur kemudahan dan ketepatan prosedur layanan, dengan koefisien rata-rata 4,42 (Tabel 5), sedangkan harapan/tingkat kepentingan unsur kualitas jasa layanan paling rendah adalah ketersediaan tempat parkir, dengan koefisien rata-rata 3,62 sesuai dengan kelas interval/rentang skala menunjukkan berpengaruh.

\section{Tabel 5}

Hasil Perhitungan Rata-rata Tingkat Harapan

Kualitas Layanan Jasa BPR BDE Pakem Sleman

\begin{tabular}{|c|c|c|c|}
\hline No & Unsur Dimesi Kualitas Jasa & Rata-rata & Kategori \\
\hline \multicolumn{4}{|c|}{ Reliability (Keandalan) } \\
\hline 1 & Ketepatan waktu layanan & 3,89 & Berpengaruh \\
\hline 2 & Profesionalisme layanan & 4,21 & Sangat Berpengaruh \\
\hline 3 & Ketepatan dan ketelitian dalam memberikan layanan & 4,10 & Berpengaruh \\
\hline 4 & Kemudahan dan ketepatan prosedur layanan & 4,42 & Sangat Berpengaruh \\
\hline \multicolumn{4}{|c|}{ Responsiveness (Daya Tanggap) } \\
\hline 5 & Kesigapan karyawan membantu nasabah & 3,97 & Berpengaruh \\
\hline 6 & Kesanggupan mengubah layanan sesuai kebutuhan nasabah & 3,93 & Berpengaruh \\
\hline 7 & Kesigapan karyawan menangani keperluan dan keluhan nasabah & 3,69 & Berpengaruh \\
\hline 8 & Tindakan layanan yang cepat saat nasabah membutuhkan & 4,27 & Sangat Berpengaruh \\
\hline \multicolumn{4}{|c|}{ Assurance (Jaminan) } \\
\hline 9 & Pengetahuan dan keakuratan informasi yang disampaikan & 4,12 & Berpengaruh \\
\hline 10 & Kemampuan karyawan dalam memberikan layanan sesuai janji & 4,11 & Berpengaruh \\
\hline 11 & Kepercayaan terhadap bank & 3,85 & Berpengaruh \\
\hline 12 & Keamanan bertransaksi & 4,28 & Sangat Berpengaruh \\
\hline \multicolumn{4}{|c|}{ Emphaty (Empati) } \\
\hline 13 & Kemampuan karyawan berkomunikasi & 3,91 & Berpengaruh \\
\hline 14 & Perhatian secara personal & 3,86 & Berpengaruh \\
\hline 15 & Layanan kepada nasabah tanpa memandang status sosial & 3,82 & Berpengaruh \\
\hline 16 & Kemudahan untuk dihubungi nasabah & 4,16 & Berpengaruh \\
\hline
\end{tabular}




\begin{tabular}{|l|l|l|c|}
\hline \multicolumn{3}{|c|}{ Tangible (wujud fisik) } & Berpengaruh \\
\hline 17 & Penampilan dan kerapihan seragam karyawan & 3,81 & Berpengaruh \\
\hline 18 & Penampilan fisik gedung & 3,86 & Berpengaruh \\
\hline 19 & Ketersediaan tempat parkir $\quad$ Rata-rata & 3,62 & Berpengaruh \\
\hline 20 & Kemudahan penjangkauan lokasi & 4,00 & Berpengaruh \\
\hline & & 4,01 & \\
\hline
\end{tabular}

Sumber: Hasil olah data penelitian, 2014.

Keterangan kategori (Simamora, 2004, hal. 59):

$1,00 \leq X \leq 1,80$ = Sangat Tidak Berpengaruh $1,81 \leq X \leq 2,60=$ Tidak Berpengaruh

$2,61 \leq X \leq 3,40=$ Cukup Berpengaruh $\quad 3,41 \leq X \leq 4,20=$ Berpengaruh

$4,21 \leq \mathrm{X} \leq 5,00=$ Sangat Berpengaruh

\section{Analisis Tingkat Kinerja Layanan BPR BDE Pakem Sleman}

Analisis berikut ini bertujuan untuk mengetahui tingkat kinerja kualitas layanan Bank BPR BDE Pakem Sleman atau untuk mengetahui seberapa besar penilaian nasabah terhadap kinerja kualitas jasa perbankan pada BPR BDE Pakem Sleman. Berdasarkan hasil perhitungan data penelitian yang terdapat pada Tabel 8 berikut, dapat dilihat bahwa nilai kinerja kualitas jasa layanan perbankan pada BPR BDE Pakem Sleman secara umum masuk kategori baik menurut nasabah, dengan nilai rerata dari rata-rata sebesar 4,10. Nilai rerata untuk dimensi reliability sebesar 3,98 yang masuk dalam kategori berpengaruh, untuk dimensi responsiveness bernilai sebesar 4,17 masuk dalam kategori berpengaruh, untuk dimensi assurance bernilai sebesar 4,24 masuk dalam kategori sangat berpengaruh, untuk dimensi emphaty bernilai sebesar 3,99 masuk dalam kategori berpengaruh dan dimensi tangible bernilai rata-rata sebesar 3,97 juga masuk dalam kategori berpengaruh. Kategori diatas sesuai dengan kelas interval/rentang skala.

Tabel 6

Hasil Perhitungan Nilai Rerata Tingkat Kinerja

Dimensi Kualitas Jasa pada BPR BDE Pakem Sleman

\begin{tabular}{|l|l|c|c|}
\hline No & Dimensi Kualitas Jasa & Nilai Rata-rata & Kategori \\
\hline 1 & Reliability & 3,98 & Berpengaruh \\
\hline 2 & Responsiveness & 4,17 & Berpengaruh \\
\hline 3 & Assurance & 4,24 & Sangat Berpengaruh \\
\hline 4 & Emphaty & 3,99 & Berpengaruh \\
\hline 5 & Tangible & 3,97 & Berpengaruh \\
\hline & Rerata dari nilai rata-rata & $\mathbf{4 , 1 0}$ & Berpengaruh \\
\hline
\end{tabular}

Sumber: Hasil olah data penelitian, 2014.

Keterangan (Simamora, 2004, hal. 59):

$1,00 \leq X \leq 1,80=$ Sangat Tidak Berpengaruh $1,81 \leq X \leq 2,60=$ Tidak Berpengaruh

$2,61 \leq X \leq 3,40=$ Cukup Berpengaruh $\quad 3,41 \leq X \leq 4,20=$ Berpengaruh

$4,21 \leq X \leq 5,00=$ Sangat Berpengaruh 
Untuk mengetahui nilai rata-rata tingkat kinerja untuk tiap unsur pada tiap dimensi kualitas jasa layanan BPR BDE Pakem Sleman dapat dilihat pada Tabel 7 berikut. Informasi yang tertera pada Tabel 7 menunjukkan bahwa tingkat kinerja dimensi kualitas jasa layanan pada BPR BDE Pakem yang paling berpengaruh menurut nasabah adalah keamanan bertransaksi dengan koefisien rata-rata 4,43 sesuai dengan kelas interval/rentang skala menunjukkan sangat berpengaruh, sedangkan tingkat kinerja dimensi kualitas jasa paling rendah menurut para nasabah adalah kemudahan untuk dihubungi nasabah dengan koefisien rata-rata 3,62 sesuai dengan kelas interval/rentang skala menunjukkan berpengaruh. Berdasarkan nilai rata-rata keseluruhan tingkat kinerja bank sebesar 4,10 dapat diartikan bahwa menurut persepsi nasabah tingkat kinerja dimensi kualitas jasa layanan perbankan pada BPR BDE Pakem Sleman masuk dalam kategori berpengaruh sesuai dengan kelas interval/rentang skala.

\section{Analisis Kesesuaian Tingkat Kinerja Dimensi Kualitas Jasa (Importance-Performance Analysis)}

Analisis kesesuaian tingkat kinerja adalah analisis untuk menentukan nilai kesesuaian tingkat kepentingan dan tingkat kinerja dimensi kualitas jasa layanan pada BPR BDE Pakem Sleman. Analisis dilakukan dengan menentukan nilai perbandingan (rasio) antara nilai rerata tingkat kepentingan dimensi kualitas jasa dengan rerata kinerja dimensi kualitas jasa. Penentuan nilai rasio ini adalah untuk setiap unsur pada masingmasing dimensi kualitas jasa. Selanjutnya angka hasil dari rasio tingkat kesesuaian ini disebut sebagai tingkat kepuasan, sehingga tingkat kesesuaian kinerja dimensi kualitas jasa adalah tingkat kepuasan nasabah

terhadap dimensi kualitas jasa layanan pada BPR BDE Pakem Sleman. Hasil perhitungan rasio seperti di dalam Tabel 8 berikut. Perhitungan pada Tabel 8 menunjukkan bahwa nilai rata-rata akhir untuk tingkat kepentingan dimensi kualitas jasa sebesar 4,02 yang masuk kategori berpengaruh. Hal ini berarti bahwa rata-rata para nasabah beranggapan bahwa tingkat kepentingan seluruh dimensi kualitas jasa pada layanan BPR BDE Pakem Sleman adalah penting. Dapat dilihat juga nilai rata-rata akhir untuk Tingkat Kinerja dimensi kualitas jasa layanan sebesar 4,10 yang masuk dalam kategori berpengaruh. Hal ini berarti bahwa rata-rata para nasabah menganggap kinerja dimensi kualitas jasa layanan perbankan dari BPR BDE Pakem Sleman adalah berpengaruh. 
Tabel 7

Hasil Perhitungan Rata-rata Tingkat Kinerja Dimensi Kualitas Jasa Layanan BPR BDE Pakem Sleman

\begin{tabular}{|c|c|c|c|}
\hline No & Unsur Dimensi Kualitas Jasa & Rata-rata & Peringkat \\
\hline \multicolumn{4}{|c|}{ Reliability (Keandalan) } \\
\hline 1 & Ketepatan waktu layanan & 4,16 & Berpengaruh \\
\hline 2 & Profesionalisme layanan & 3,81 & Berpengaruh \\
\hline 3 & Ketepatan dan ketelitian dalam memberikan layanan & 3,69 & Berpengaruh \\
\hline 4 & Kemudahan dan ketepatan prosedur layanan & 4,27 & Sangat Berpengaruh \\
\hline \multicolumn{4}{|c|}{ Responsiveness (Daya Tanggap) } \\
\hline 5 & Kesigapan karyawan membantu nasabah & 4,21 & Sangat Berpengaruh \\
\hline 6 & Kesanggupan mengubah layanan sesuai kebutuhan nasabah & 4,10 & Berpengaruh \\
\hline 7 & Kesigapan karyawan menangani keperluan dan keluhan nasabah & 4,42 & Sangat Berpengaruh \\
\hline 8 & Tindakan layanan yang cepat saat nasabah membutuhkan & 3,97 & Berpengaruh \\
\hline \multicolumn{4}{|c|}{ Assurance (Jaminan) } \\
\hline 9 & Pengetahuan dan keakuratan informasi yang disampaikan & 4,19 & Berpengaruh \\
\hline 10 & Kemampuan karyawan dalam memberikan layanan sesuai janji & 4,27 & Sangat Berpengaruh \\
\hline 11 & Kepercayaan terhadap bank & 4,07 & Berpengaruh \\
\hline 12 & Keamanan bertransaksi & 4,43 & Sangat Berpengaruh \\
\hline \multicolumn{4}{|c|}{ Emphaty (Empati) } \\
\hline 13 & Kemampuan karyawan berkomunikasi & 4,28 & Sangat Berpengaruh \\
\hline 14 & Perhatian secara personal & 3,97 & Berpengaruh \\
\hline 15 & Layanan kepada nasabah tanpa memandang status sosial & 4,09 & Berpengaruh \\
\hline 16 & Kemudahan untuk dihubungi nasabah & 3,62 & Berpengaruh \\
\hline \multicolumn{4}{|c|}{ Tangible (Wujud Fisik) } \\
\hline 17 & Penampilan dan kerapihan seragam karyawan & 3,93 & Berpengaruh \\
\hline 18 & Penampilan fisik gedung & 4,27 & Sangat Berpengaruh \\
\hline 19 & Ketersediaan tempat parkir & 3,85 & Berpengaruh \\
\hline 20 & Kemudahan penjangkauan lokasi & 3,86 & Berpengaruh \\
\hline \multicolumn{2}{|r|}{ Rata-rata } & 4,10 & Berpengaruh \\
\hline
\end{tabular}

Sumber: Hasil olah data penelitian, 2014.

Keterangan (Simamora, 2004, hal. 59):

$1,00 \leq X \leq 1,80$ = Sangat Tidak Berpengaruh $1,81 \leq X \leq 2,60=$ Tidak Berpengaruh

$2,61 \leq X \leq 3,40=$ Cukup Berpengaruh $\quad 3,41 \leq X \leq 4,20=$ Berpengaruh

$4,21 \leq \mathrm{X} \leq 5,00=$ Sangat Berpengaruh 
Tabel 8

Tingkat Kepuasan Nasabah Terhadap Kinerja Dimensi

Kualitas Jasa Layanan BPR BDE Pakem Sleman

\begin{tabular}{|c|c|c|c|c|c|}
\hline No & Unsur Dimensi Kualitas Jasa & $\begin{array}{l}\text { Rata-rata } \\
\text { Kinerja } \\
(\bar{X})\end{array}$ & $\begin{array}{c}\text { Rata-rata } \\
\text { Kepentingan } \\
(\bar{Y})\end{array}$ & $\begin{array}{l}\text { Tingkat } \\
\text { Kepuasan } \\
(\mathrm{X} / \mathrm{Y})(\%)\end{array}$ & Kategori \\
\hline \multicolumn{6}{|c|}{ Reliability (Keandalan) } \\
\hline 1 & Ketepatan waktu layanan & 4,16 & 3,89 & 106,94 & Sangat Puas \\
\hline 2 & Profesionalisme layanan & 3,81 & 4,21 & 90,50 & Puas \\
\hline 3 & Ketepatan dan ketelitian & 3,69 & 4,10 & 90,00 & Puas \\
\hline 4 & Kemudahan dan ketepatan prosedur & 4,27 & 4,42 & 96,61 & Puas \\
\hline \multicolumn{6}{|c|}{ Responsiveness (Daya Tanggap) } \\
\hline 5 & $\begin{array}{l}\text { Kesigapan karyawan membantu } \\
\text { nasabah }\end{array}$ & 4,21 & 3,97 & 106,05 & Sangat Puas \\
\hline 6 & $\begin{array}{l}\text { Kesanggupan mengubah layanan sesuai } \\
\text { kebutuhan nasabah }\end{array}$ & 4,10 & 3,93 & 104,33 & Sangat Puas \\
\hline 7 & $\begin{array}{l}\text { Kesigapan karyawan menangani } \\
\text { keperluan dan keluhan nasabah }\end{array}$ & 4,42 & 3,69 & 119,78 & Sangat Puas \\
\hline 8 & $\begin{array}{l}\text { Tindakan layanan yang cepat saat } \\
\text { nasabah membutuhkan }\end{array}$ & 3,97 & 4,27 & 92,97 & Puas \\
\hline \multicolumn{6}{|c|}{ Assurance (Jaminan) } \\
\hline 9 & $\begin{array}{l}\text { Pengetahuan dan keakuratan informasi } \\
\text { yang disampaikan }\end{array}$ & 4,19 & 4,24 & 98,82 & Puas \\
\hline 10 & $\begin{array}{l}\text { Kemampuan karyawan dalam } \\
\text { memberikan layanan }\end{array}$ & 4,27 & 4,23 & 100,95 & Sangat Puas \\
\hline 11 & Kepercayaan terhadap bank & 4,07 & 3,97 & 102,52 & Sangat Puas \\
\hline 12 & Keamanan bertransaksi & 4,43 & 4,40 & 100,68 & Sangat Puas \\
\hline \multicolumn{6}{|c|}{ Emphaty (Empati) } \\
\hline 13 & $\begin{array}{l}\text { Kemampuan karyawan } \\
\text { berkomunikasi }\end{array}$ & 4,28 & 3,91 & 109,46 & Sangat Puas \\
\hline 14 & Perhatian secara personal & 3,97 & 3,86 & 102,85 & Sangat Puas \\
\hline 15 & $\begin{array}{l}\text { Layanan kepada nasabah tanpa } \\
\text { memandang status sosial }\end{array}$ & 4,09 & 3,82 & 107,07 & Sangat Puas \\
\hline 16 & Kemudahan untuk dihubungi nasabah & 3,62 & 4,16 & 87,02 & Puas \\
\hline \multicolumn{6}{|c|}{ Tangible (wujud fisik) } \\
\hline 17 & $\begin{array}{l}\text { Penampilan dan kerapian seragam } \\
\text { karyawan }\end{array}$ & 3,93 & 3,81 & 103,15 & Sangat Puas \\
\hline 18 & Penampilan fisik gedung & 4,27 & 3,86 & 110,62 & Sangat Puas \\
\hline 19 & Ketersediaan tempat parkir & 3,85 & 3,62 & 106,35 & Sangat Puas \\
\hline \multirow[t]{2}{*}{20} & Kemudahan penjangkauan lokasi & 3,86 & 4,00 & 96,50 & Puas \\
\hline & \begin{tabular}{|c|} 
Total rata-rata \\
\end{tabular} & 4,10 & 4,02 & 101,66 & Sangat Puas \\
\hline
\end{tabular}

Sumber: Hasil olah data penelitian, 2014.

Keterangan (Supranto, 2001, hal. 241):
$0-25 \%$
$=$ Sangat Tidak Puas 25,1-50\%
$=$ Tidak Puas
$50,1-75 \%=$ Cukup Puas 75,1-100\%
$=$ Puas

Lebih dari $100 \% \quad=$ Sangat Puas

Selanjutnya, rasio antara rata-rata Tingkat Kinerja $(X)$ dan rata-rata Tingkat Kepentingan (Y) tersebut menghasilkan Tingkat Kesesuaian (TK) nilai rerata tingkat kinerja dan nilai rerata tingkat harapan/kepentingan dimensi kualitas layanan jasa yang tidak lain merupakan Tingkat Kepuasan nasabah atas dimensi kualitas jasa layanan BPR BDE Pakem 
Sleman. Nilai Tingkat Kesesuaian (TK) yang disebut juga sebagai Tingkat Kepuasan nasabah atas dimensi kualitas jasa layanan BPR BDE Pakem Sleman. Berdasarkan perhitungan pada Tabel 8 tersebut dapat ditunjukkan pula bahwa tingkat kepuasan nasabah BPR BDE Pakem Sleman untuk seluruh unsur dimensi kualitas jasa antara kategori puas dan sangat puas. Nilai rerata Tingkat Kepuasan untuk seluruh unsur pada dimensi kualitas jasa layanan adalah sebesar 101,66\% yang berarti masuk dalam kategori "sangat puas" sesuai dengan tingkat kepuasan pelanggan, sehingga seluruh responden merasa sangat puas dengan dimensi kualitas layanan jasa BPR BDE Pakem Sleman.

Tabel 9

Rekapitulasi Nilai Rata-rata Kepuasan Tiap Dimensi Kualitas Jasa Layanan BPR BDE Pakem Sleman

\begin{tabular}{|l|l|r|c|}
\hline \multicolumn{1}{|c|}{ No. } & \multicolumn{1}{|c|}{ Dimensi Kualitas Jasa } & $\begin{array}{r}\text { Nilai Rata-Rata Kepuasan } \\
\text { (\%) }\end{array}$ & Kategori \\
\hline 1. & Reliability & $\mathbf{9 6 , 0 1}$ & Puas \\
\hline 2. & Responsiveness & $\mathbf{1 0 5 , 7 8}$ & Sangat Puas \\
\hline 3. & Assurance & 100,74 & Sangat Puas \\
\hline 4. & Emphaty & 101,60 & Sangat Puas \\
\hline 5. & Tangible & 104,15 & Sangat puas \\
\hline \multicolumn{2}{|r|}{ Rerata dari nilai rata-rata } & 101,66 & Sangat Puas \\
\hline
\end{tabular}

Sumber: Hasil olah data penelitian, 2014.

Keterangan (Supranto, 2001, hal. 241):

$\begin{array}{lll}0-25 \% & =\text { Sangat Tidak Puas } & 25,1-50 \%=\text { Tidak Puas } \\ 50,1-75 \% & =\text { Cukup Puas } & 75,1-100 \%=\text { Puas }\end{array}$

Lebih dari $100 \%$ = Sangat Puas

Dari Tabel 9 tersebut dapat dilihat bahwa nilai rata-rata kepuasan tertinggi dari seluruh dimensi kualitas layanan adalah pada dimensi responsiveness dengan nilai rerata kepuasan 105,78\%, sedangkan nilai kepuasan yang paling rendah pada dimensi reliability dengan nilai rerata kepuasan sebesar 96,01\%. Dari uraian di atas, lebih jauh dapat juga disimpulkan bahwa secara keseluruhan nasabah merasa sangat puas dengan kualitas layanan jasa BPR BDE Pakem Sleman dengan kepuasan tertinggi pada unsur kesigapan karyawan menangani keperluan dan menyelesaikan keluhan nasabah. Untuk tingkat kepuasan yang paling rendah menurut nasabah adalah kemudahan dihubungi nasabah.

\section{Analisis Diagram Kartesius}

Hasil perhitungan nilai rerata dari rata-rata variabel $X$ dan $Y$ dimasukkan ke dalam suatu diagram kartesius untuk melihat di titik koordinat mana terletak nilai unsur-unsur dalam variabel $\mathrm{X}$ dan $\mathrm{Y}$ pada 
kuadran A, B, C, dan D. Kedudukan dari titik-titik koordinat akan menunjukkan hubungan tingkat pelaksanaan dalam tingkat harapan dimensi kualitas jasa layanan nasabah pada BPR BDE Pakem Sleman. Pada penelitian ini, nilai $\mathrm{X}$ dan $\mathrm{Y}$ yang telah dimasukkan ke dalam diagram kartesius adalah sebagai berikut:

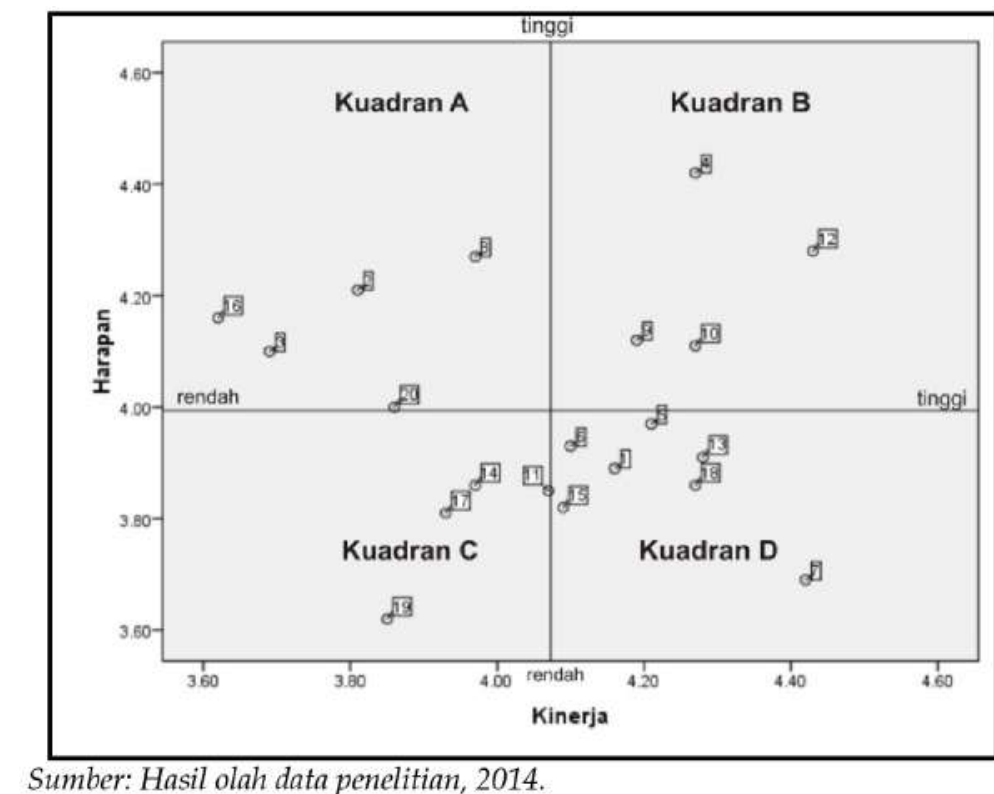

Gambar 4

Unsur-unsur Kualitas Jasa dalam Diagram Kartesius

Berdasarkan Diagram Kartesius tersebut di atas, dapat diambil beberapa kesimpulan sebagai berikut:

1. Kuadran A menunjukkan unsur-unsur dimensi kualitas jasa yang dianggap mempengaruhi kepuasan nasabah, pada BPR BDE Pakem Sleman, unsur-unsur yang masuk dalam kuadran ini harus menjadi "prioritas utama" untuk segera diperbaiki. Unsur kualitas jasa layanan bank yang masuk dalam kuadran ini adalah: (a) profesionalisme layanan, (b) ketepatan dan ketelitian dalam memberikan layanan, (c) layanan yang cepat saat nasabah membutuhkan, (d) kemudahan untuk dihubungi nasabah, serta (e) kemudahan untuk menjangkau lokasi.

2. Kuadran B menunjukkan unsur-unsur dimensi kualitas jasa yang telah berhasil dilaksanakan baik oleh bank, untuk itu bank harus mempertahankan prestasinya, karena telah dianggap sangat berpengaruh dan sangat memuaskan. Unsur layanan yang masuk dalam kuadran ini adalah: (a) kemudahan dan ketepatan prosedur layanan, (b) kemampuan karyawan dalam memberikan layanan sesuai janji yang diberikan, serta (c) keamanan bertransaksi. 
3. Kuadran $\mathrm{C}$ menunjukkan unsur-unsur dimensi kualitas jasa yang dianggap kurang berpengaruh bagi nasabah, pelaksanaannya dianggap biasa-biasa saja, kurang berpengaruh dan kurang memuaskan, sehingga unsur-unsur yang masuk dalam layanan ini dianggap sebagai prioritas rendah dibandingkan unsur-unsur lain yang masuk dalam tiga kuadran lainnya. Unsur kualitas jasa layanan yang masuk dalam kuadran ini adalah: (a) kepercayaan terhadap bank, (b) perhatian secara personal, (c) penampilan dan kerapian seragam karyawan, dan (d) ketersediaan tempat parkir.

4. Kuadran D menunjukkan unsur-unsur dimensi kualitas jasa layanan yang mempengaruhi nasabah, tetapi masih dianggap kurang berpengaruh. Unsur-unsur layanan BPR BDE Pakem Sleman yang masuk dalam kuadran ini adalah: (a) ketepatan waktu layanan, (b) kesigapan karyawan membantu keperluan/informasi yang dibutuhkan nasabah, (c) kesanggupan mengubah layanan sesuai kebutuhan nasabah, (d) kesigapan karyawan menangani keperluan dan menyelesaikan keluhan nasabah, (e) kemampuan karyawan berkomunikasi, (f) layanan nasabah tanpa memandang status sosial, dan (g) penampilan fisik gedung.

\section{KESIMPULAN}

Berdasarkan hasil analisis data di atas yang meliputi analisis rerata aritmatika dan analisis tingkat pengaruh dimensi kualitas jasa, tingkat harapan dimensi kualitas jasa layanan, tingkat kinerja layanan, dan diagram Kartesius dapat disimpulkan sebagai berikut:

1. Menurut nilai rata-rata kepuasan tiap dimensi kualitas jasa layanan BPR BDE Pakem Sleman secara umum nasabah merasa sangat puas dengan nilai tingkat kesesuaian atau tingkat kepuasan sebesar 101,66 $\%$ (sangat puas).

2. Dimensi emphaty dianggap paling berpengaruh terhadap keputusan nasabah dalam menggunakan jasa layanan BPR BDE Pakem Sleman sebesar 4,43 (sangat berpengaruh).

3. Menurut hasil analisis diagram kartesius dapat dijabarkan sebagai berikut:

a. Unsur layanan yang diangap sangat berpengaruh oleh nasabah, tetapi nasabah tidak merasa puas, sehingga unsur-unsur layanan yang menjadi prioritas utama untuk segera diperbaiki adalah profesionalisme layanan, ketepatan dan ketelitian dalam memberikan layanan, tindakan layanan yang cepat saat nasabah membutuhkan, kemudahan untuk dihubungi nasabah, serta kemudahan untuk menjangkau lokasi. Hal ini tercantum pada kuadran A. 
b. Unsur layanan yang dianggap berpengaruh oleh nasabah dan sangat memuaskan, serta prestasi pada unsur-unsur layanan yang harus tetap dipertahankan dan ditingkatkan adalah kemudahan dan ketepatan prosedur layanan, kemampuan karyawan dalam memberikan layanan sesuai janji yang diberikan, serta keamanan bertransaksi. Hasil ini tercantum pada kuadran B.

c. Unsur layanan yang dianggap cukup berpengaruh oleh nasabah, kurang memuaskan dan dianggap sebagai prioritas rendah dibandingkan unsur-unsur lain adalah kepercayaan terhadap bank, perhatian secara personal, penampilan dan kerapihan seragam karyawan, dan ketersediaan tempat parkir. Hasil ini tercantum pada kuadran C.

d. Unsur layanan yang dianggap tidak berpengaruh oleh nasabah, tetapi dalam pelaksanaannya berlebihan, sehingga sangat memuaskan nasabah adalah ketepatan waktu layanan, kesigapan karyawan membantu keperluan serta informasi yang dibutuhkan nasabah, kesanggupan mengubah layanan sesuai kebutuhan nasabah, kesigapan karyawan menangani keperluan dan menyelesaikan keluhan nasabah, kemampuan karyawan berkomunikasi, layanan kepada nasabah tanpa memandang status sosial, dan penampilan fisik gedung. Hasil ini tercantum pada kuadran D. 


\section{DAFTAR PUSTAKA}

BPR BDE Pakem Sleman, (2013), (http://www.bprbde.co.id., diakses pada tanggal 2 Juni).

Dharmmesta dan Irawan, (2005), Manajemen Pemasaran Modern, Edisi Kedua. Yogyakarta: Liberty.

Dharmmesta, B.S. dan Handoko, H., (2000), Manajemen Pemasaran, Analisa Perilaku Konsumen, Yogyakarta: BPFE.

Gaspersz, Vincent, (1997), Manajemen Kualitas dalam Industri Jasa, Jakarta: Gramedia Pustaka Utama.

Hart, J. dan Stapleton, (1992), Marketing Dictionary, Oxford: ButterworthHeinemann, Ltd.

Hartono, (2005), “Analisis Kualitas Layanan terhadap Kepuasan Nasabah PT. Bank Jateng Cabang Purworejo." Tesis, MM-UMS, Surakarta.

Kasmir, (2004), Manajemen Perbankan. Jakarta: Rajagrafindo Persada.

Kotler, P. \& Amstrong (2006), Prinsip-Prinsip Pemasaran, Jakarta: Erlangga.

Kotler,P ., (2004), Manajemen Pemasaran, Edisi Millenium, Jakarta: PT. Prenhallindo.

Lupiyoadi dan Hamdani, (2006), Manajemen Pemasaran, Jakarta: Salemba Empat.

Schnaars, Steven P, (1994), Managing Imitation Strategies. New York: The Free Press.

Sekaran, Uma, (2006), Metodologi Penelitian untuk Bisnis. Edisi 4, Buku 1, Jakarta: Salemba Empat.

Simamora, Bilson, (2004), Riset Pemasaran Falsafah, Teori dan Aplikasi. Jakarta: PT. Gramedia Pustaka Utama.

Sudarmiatin, (2009), "Model Perilaku Konsumen dalam Perspektif Teori dan Empiris pada Jasa Pariwisata. "Jurnal ekonomi dan bisnis tahun 14 no. 1.

Supranto, J., (2001) Statistik Teori dan Aplikasi, Jakarta: Rineka Cipta.

(2001), Pengukuran Tingkat Kepuasan Pelanggan: Untuk Menaikkan Pangsa Pasar, Jakarta: Rineka Cipta.

Tjiptono, Fandy, (2006), Manajemen Jasa. Edisi Kedua, Yogyakarta: Penerbit ANDI OFFSET.

Umar, Husein, (2004), Metode Riset Perilaku Organisasi, Jakarta: PT. Gramedia Pustaka Utama.

Zeithmal \& Berry, (1988), "Servqual: Multiple Item Scaling for Measuring Consumer Perceptions of Service Quality." Journal of Retailing, Vol. 64. 